\title{
Blood, Sweat, and Tears: Self-Chastisement in Donne's "If poysonous mineralls"
}

\section{KENNETH CHONG}

Les principales interprétations du poème de Donne - "If poysonous mineralls" - sont divisées sur la question de savoir si le propos de ce poème est spécieux ou non. Mon avis est qu'il est effectivement spécieux, mais seulement dans la perspective où l'auteur se repent et se châtie. La stratégie rhétorique que Donne utilise dans ce poème - c'est-à-dire un parcours de l'objection vers l'autocorrection - est la même, d'après mon analyse, que celle de Paul dans Romains 9. Ce sont les similarités structurelles et verbales qui font que le poème de Donne évoque pour l'auteur et le lecteur ce chapitre de la Bible. C'est pourquoi je propose que l'auteur a appliqué les Écritures à lui-même, autant qu'au lecteur, et que de cette manière le sonnet ne fonctionne pas seulement comme un témoignage privé de la foi de Donne mais également comme un modèle public de dévotion.

Tn his essay on Donne, John Stachniewski states that the sonnet "If poysonlous mineralls" is "a variation on the technique of subverting reason": its speaker makes an emotional protest "until it mounts to a blasphemous climax," but is overpowered by a God whose "unreasonableness is of no force as an argument against Him." in the first eight lines of the poem is rejected, not because it is unreasonable, but precisely because it is reasonable. And the protests, although emotional, are "not illogical"; for even though Barbara Lewalski notes that the complaint of God preferring retribution over mercy is "a specious argument, as [the speaker] recognizes in his outcry," it is an argument that has, for Stachniewski, no "textual warrant" $(695){ }^{2}$ Rather the outcry of the speaker, Stachniewski argues, is not a recognition that the argument is specious but a recognition that the speaker "should not advance any argument against God" 
(695; emphasis mine). Richard Strier has more recently argued, however, that the poem "presents a clear instance of deliberate sophistry." 3 Indeed, "the argument of the octet is presented in such a way as to call attention to its own lack of seriousness"; the "textual warrant" for its speciousness is not so much found as given to the reader (382). It seems, then, that for Strier (and Lewalski) the poem contains a logically fallacious argument that can easily be dismissed; but for Stachniewski it contains a logically sound argument that must be suppressed or short-circuited because it threatens to undermine the mercy and justice of God. My answer to the question that is informing this debate-Is the argument of the poem specious? - is yes, but that speciousness is only recognized (by the speaker and the reader) at the point the speaker chastises himself and weeps in repentance. What I would like to suggest is that the argument has a prima facie reasonableness: the unrepentant reader is initially lead to believe that it is entirely reasonable until the argument of the octet is questioned by the speaker in the lines that follow it; and the reader, now aware of his or her own sinfulness (as exemplified in the reading of the poem), is brought to repentance in the same way as the speaker. The basis for the rhetorical strategy that Donne uses here, I believe, can be found in Paul's epistle to the Romans.

At the start of chapter nine in his epistle to the Romans, Paul wishes that he could be "accursed from Christ" for his brethren, his "kinsemen according to the flesh." ${ }^{4}$ By "brethren" and "kinsemen" Paul is referring to the Israelites - who were given the covenants, the law, and the promises, and were marked out for adoption and glory - and he is lamenting because many of them will not have what should be theirs, for they have failed to accept the grace that comes from Christ. But this does not mean, Paul explains, that "the word of God hath taken none effect" (9:6). Instead, it shows that everyone who claims to be an Israelite is not necessarily a true Israelite, for some may be the "children of the flesh" and therefore "not the children of God" (9:8). It is only the "children of the promise" who are counted as children of God, and that status is given not on the basis of works but on the call of God, i.e., his election. The word of promise given to Rebecca- "The elder shall serue the yonger" (12) - is a case in point: "For the children being not yet borne, neither having done any good nor evil, that the purpose of God according to election might stand, not of workes, but of him that calleth" (9:11). As a result, God chooses to favour Jacob over Esau: "As it is written, Jacob I loved, but Esau I hated" (9:13). It is at this point that Paul anticipates and answers a possible objection to God's sovereign election: 
What shall we say then? Is there vnrighteousness with God? God forbid. For hee saith to Moses, I will have mercy on whom I will haue mercy, and I will have compassion on whom I haue compassion.

So then it is not of him that willeth, nor of him that runneth, but of God that sheweth mercy.

For the Scripture saith vnto Pharaoh, Euen for this same purpose I raised thee vp, that I might shew my power in thee, and that my Name might bee declared throughout all the earth.

Therefore he hath mercy on whom he will haue mercy, and whom he will, he hardeneth. (9:14-18)

God is not unrighteous because mercy is something that cannot be earned but can only be granted by the one who has the power to do so. That is, God chooses not on the basis of any external evidence or merit; he chooses those on whom he will have mercy and those on whom he will harden on the basis of nothing other than himself.

The previous sentence is a typical statement of the approach usually named "voluntarism," an approach frequently attributed to Duns Scotus and William of Ockham and one that was held by the Reformation theologians. Generally speaking, the voluntarist approach to understanding the essential relationship between God and morality emerged in response to the problematic conclusions of the natural law tradition. In this "rationalist" or "intellectualist" tradition, originating from the Stoics and systematized in Christian thought by Aquinas, man is able to demand justly a reason for any fundamental moral rule and is obligated to follow those rules, since God was the one who willed them. In order to be consistent, however, God can only will what can be rationally understood as good for man; the corollary is that God cannot choose what is not rationally available to man, that is, cannot choose what is not good. It seems, then, that the two (Thomistic) premises presented here limit God's freedom and therefore his omnipotence. James Tully points out that the "voluntarist school resolves this problem in a radical way": "To save god's freedom they deny the premise that a necessary condition of a natural law, and so any law, is that it can be shown to be good for man. A law is a law if it is enacted by an authoritative lawgiver and promulgated. Thus, god's will is good, and just, because he wills it, and not because it is conformable to independent criteria of 'good' or 'just' that are rationally apprehendable by man." Rather than prescribing moral laws on the basis of his knowledge of eternal standards (and ensuring that we inhabit a morally ordered world by his providence), God determines those laws - what is right and wrong, what is good and evil—only in relation to himself. Or, as J. B. Schneewind puts it, "Voluntarists hold that God created morality and imposed it upon us by an arbitrary fiat of his will. He is essential to morality, therefore, because he 
created it and can always, in principle, alter it - as he seems to do on those rare occasions, such as commanding Abraham to sacrifice Isaac, when he intervenes in it."6

Martin Luther, who devoted so much of his writings against the teaching of the Catholic church, affirms this voluntarist position in The Bondage of the Will. After establishing that the heart of Pharaoh is hardened by virtue of the ruler's natural corruption and evil will, a hardening that is simultaneously caused by the movement of divine omnipotence, Luther feels that it is not necessary to withdraw the claim that God is actively operating in everything (including evil wills), even though it seems to leave the deity's righteousness open to challenge. To the question "Why then does He not alter those evil wills which He moves?" Luther responds by acknowledging that such inquiries enter the realm of mystery, and it is "not for us to inquire into these mysteries, but to adore them." For those who take offence and grumble at such an answer, however, Luther offers the following defence:

\footnotetext{
The same reply should be given to those who ask: Why did God let Adam fall, and why did He create us all tainted with the same sin, when He might have kept Adam safe, and might have created us of other material, or of seed that had first been cleansed? God is He for Whose will no cause or ground may be laid down as its rule and standard; for nothing is on a level with it or above it, but it is itself the rule for all things. If any rule or standard, or cause or ground, existed for it, it could no longer be the will of God. What God wills is not right because He ought, or was bound, so to will; on the contrary, what takes place must be right, because He so wills it. (195-96)
}

In short, Luther objects to the rationalist position that there is some independent standard to which God must conform, a position that makes God subordinate to something or someone else; rather, he accepts the voluntarist position that what counts as right and wrong is a function of God's will, and consequently admits that we cannot comprehend God or judge what he decrees.

It is this conclusion that Paul reaches in his answer to the question of God's righteousness, one that provokes another possible objection; but this time it is posed by an imaginary questioner: "Thou wilt say then vnto me, Why doeth he yet find fault? For who hath resisted his will?" (9:19). In other words, "How can God fault my sins and damn me when he is responsible for making me sinful?" The shift from the general objection of verse 14 to the objection made by an imaginary person (as signalled by the change from the first-person plural to the second-person singular) is significant because it indicates Paul's choice of rhetorical strategy or technique, a technique the ancient rhetoricians called prosopopoeia or speech-in-character. "Speech-in- 
character," Stanley K. Stowers notes, "is a rhetorical and literary technique in which the speaker or writer produces speech that represents not himself or herself but another person or type of character." acter was often in the first-person singular because it was a technique that had the power "not only to portray moral habits but also to depict and elicit emotion," it could also "take the form of monologue, soliloquy, address, and dialogue or a combination of these" (20). Thus the apostrophes, dialogue, and some of the first-person speech in Romans are types of speech-in-character, for "Quintilian places all these kinds of speech involving imaginary speakers, interlocutors, or addressees under prosopopoeia. According to Quintilian's categories, almost all of the dialogical techniques characteristic of the socalled diatribe would be types of speech-in-character" (20). Frequently "speech-in-character served as a technique for moral instruction and exhortation" (20), as is demonstrated by the apostrophe in the first five verses of Romans 2:

Therefore, thou art inexcusable, O man, whosoever thou art that iudgest: for wherein thou judgest another, thou condemnest thy selfe; for thou that iudgest doest the same things.

But wee are sure that the judgment of God is according to trueth, against them which commit such things.

And thinkest thou this, O man, that iudgest them which doe such things, and doest the same, that thou shalt escape the iudgment of God?

Or despisest thou the riches of his goodnesse, and forbearance, and long suffering, not knowing that the goodness of God leadeth thee to repentance?

Stowers explains the way in which the "speech-in-character" of this passage - a passage that is a sudden shift from Paul's description of the vices to which the Gentiles have fallen at the end of chapter one-functions for its audience:

The teacher giving the diatribe speaks to an imaginary person who represents a certain vice. The apostrophe characterizes this type of person, and the sharp censure for students in the audience who fit the type. The teacher, who has been speaking abstractly of this type of behavior, uses the apostrophe to drive the message home in a sharp but indirect way that criticizes any hearers to whom the indictment is applicable. These apostrophes are hortatory and were used in such practical social contexts as that of teachers molding the characters of their disciples according to certain patterns. (11-12)

The intended effect of censure and indictment for the readers who identify with certain vices equally applies to the apostrophe in Romans 9, although the one giving the response to the charge- - "Thou wilt say then unto 
me, Why doth he yet find fault? For who hath resisted his will?"-is not a Jewish teacher but Paul himself, a response that is given in a way that marks a decisive change in the direction of the prose:

Nay but $\mathrm{O}$ man, who art thou that repliest against [margin: disputest with] God? Shall the thing formed say to him that formed it, Why hast thou made me thus?

Hath not the potter power ouer the clay, of the same lumpe, to make one vessell vnto honour, and another vnto dishonour?

What if God, willing to shew his wrath, \& to make his power knowen, indured with much long suffering the vessels of wrath fitted to destruction:

And that he might make known the riches of his glory on the vessels of mercy, which hee had afore prepared vnto glory?

Euen vs whom he hath called, not of the Iewes onely, but also of the Gentiles? (9:20-24)

The response that Paul gives is not so much an answer as it is a rebuke. His purpose is not to satisfy the rationalizing tendencies of the imaginary questioner but to shut those tendencies down. For it is now Paul's turn to ask the questions, to question the questioner, to remind him in his cry "O man" that he is only a man, i.e., not equal to deity, and therefore in no position to dispute with God ("O man, who art thou that disputest with God?"). Indeed, the response is simultaneously a rebuke to the readers who identify with the vice of the imaginary person, a censure and indictment of those who, in their complaints that God cannot justly punish those whom he hardens, "fit the type." In his succession of rhetorical questions, which do the work of chastisement, Paul declares the futility and absurdity of disputing the creator, the one who is able (contrary to the wisdom of the world) to make his glory and power known not only through vessels of mercy but through vessels of wrath. Paul's rhetorical strategy, then, is not to provide an answer to such objections on their own terms, but to chastise the ones who make these objections (interlocutors and readers) for offering them in the first place.

Like the imaginary questioner in chapter nine of Romans, the speaker at the beginning of "If poysonous mineralls" makes an objection:

If poysonous mineralls, and if that tree,

Whose fruit threw death on else immortall us,

If lecherous goats, if serpents envious

Cannot be damn'd; Alas; why should I bee? ${ }^{9}$

That is, "If creatures and created things, which collude in our destruction, cannot be damned, then I should not be damned." The structure of the objection (presumably made to God) is like that of a hypothetical. It starts with the 
conditional marker "if"- - a marker that is repeated four times (as if to draw attention to the rationalizing processes of the speaker) — but ends with not a statement but a question. The emotion of the protest is emphasized not only by the figurative aspect of the utterance (i.e., anaphora) and the interjection "Alas," but by the shift from the plural ("us") to the singular pronoun ("I"), a shift that parallels the one from the plural ("we") to the singular pronoun ("thou") in Romans 9:14-24. It is at this point in the poem that the speaker (and the reader) feel they have been unfairly treated; but the protest, of course, goes unanswered, encouraging the speaker to offer another objection:

Why should intent or reason, borne in mee,

Make sinnes, else equall, in mee, more heinous? (5-6)

The objection here builds on the previous one: the speaker complains that it makes no sense that "intent or reason" renders him liable for damnation; after all, nature and its creatures are just as bad (and they are not damned). And even if he were to accept that "intent or reason" were decisive enough to warrant his damnation, the fact that he has reason at all is not his fault: the phrase "borne in mee" suggests that the speaker did not originate his reason but that it was originated in him. In other words, he was acted upon by another agent (God?), an agent who endowed him with a faculty that would bring about his downfall. In this the speaker aligns himself with the imaginary questioner of Romans 9: both claim that an almighty deity is ultimately responsible for the way they think and act. The objections up till now have implied or assumed an argument that consists of four statements: animals such as goats and serpents are not damned; I am damned; intent or reason make my sins more heinous than the sins of animals; I am not responsible for my intent or reason. It is on the basis of this argument that the speaker is able to lead us to the (now obvious) conclusion that God is unfair in his judgment. But even if these objections do not hold, there is still one more objection made by the speaker for why he should not be damned:

And mercy being easie, 'and glorious

To God, in his sterne wrath, why threatens hee? (7-8)

This rationale differs from the previous two. The speaker says that God should not threaten with his wrath, not because we are undeserving of it, but because his mercy is easy and brings him glory. In effect, the speaker is suggesting that God glorifies himself when he exercises mercy, but when God fails to exercise mercy he fails to glorify himself. 
This is a powerful argument - it attempts to undermine God's character and his central purpose of creating the world to bring glory to himself - and its power is intensified by the first mention of "God" in the sonnet and the urgent question at the end of line 8 ("why threatens hee?"). With each successive question, of which this is the third, the tension has been building up to a climax, a tension that demands to be resolved by the following lines:

But who am I, that dare dispute with thee?

O God ... (9-10)

The change of direction is not unexpected by the reader, as is indicated by the structural design of the sonnet; what is unexpected, however, is the way in which it is accomplished. The questions posed in the octet are answered not by an explanation but by a rebuke. In his cry "But who am I, that dare dispute with thee? / O God" the speaker recalls the rhetorical questions of Paul and appropriates them to his situation: "Nay but $\mathrm{O}$ man, who art thou that disputest with God?" (9:20). ${ }^{10}$ That is to say, the speaker chastises himself with a verse from Romans - the severity of which is marked by his exclamatio or apostrophe ("O God") and his personal address to God ("thee") - and in doing so shuts down the rationalizing processes that caused him to question God in the first place. Thus the strategy that Donne uses here (the structural and tonal turn) is the same strategy that Paul uses in Romans 9, and it is both the structural similarity and the biblical reference which brings to mind that Pauline chapter of Scripture. As the speaker remembers the content of this chapter - that God cannot be accused of unrighteousness, that he chooses of his own will on whom he will have mercy and on whom he will harden, that he is able to reveal his power and glory through displays of mercy as well as displays of wrath - he is able to respond to his initial argument and recognize its speciousness.

As readers, we share in these claims; for the action of reading the poem is imitative of the speaker's protests and his subsequent chastisement: the reader is invited to affirm the initial complaints of the speaker that are followed by a rebuke or censure, a rebuke that is also applicable to the reader who sympathizes with those complaints. One might object by saying that the substitution of the first-person pronoun "I" for the second-person pronoun "thou" of Romans in the sonnet means that Donne is not drawing on the ancient rhetorical technique of speech-in-character found in Paul's epistle, and therefore the reader is not implicated in the censure or indictment of the speaker's argument. The reverse, however, is true. In his discussion on speech-in-character in the context of ancient rhetoric, Stowers notes that "prosopopoeia was often in the first person singular," for that mode of ad- 
dress enabled authors to "portray moral habits," make "appeals to pity," and "depict and elicit emotion" (20). It follows, then, that by choosing the firstperson over the second-person pronoun, Donne intensifies rather than weakens the reader's participation in the speaker's fortunes and is indeed more effective in helping the reader identify, at least on an emotional level, with the speaker and his attitude. As P. M. Oliver has recently observed of the sonnet, "one feels that Donne's 'I' and 'me' are representative pronouns." 11 Thus the movement of the poem in which the speaker entertains an argument that he subsequently recognizes is specious is simultaneously felt by the reader; and it is in this way that Donne is able to drive his message home to his readers, to mold their character to a pattern that conforms to Scripture, to perform an act of admonishment and rebuke, one that is pedagogically superior because the readers are compelled to perform it (as the speaker does) on themselves.

When I say that the speaker recognizes that the argument is specious, I mean it not in the way that it has often been construed. In claiming that the first protest "has not been illogical," and that "Donne only recognizes that he should not advance any argument against God, not that he sees that this argument [in lines 7-8] is unfounded, nor even that it must, objectively, be false," Stachniewski is contending that the argument is not specious, that is, not unreasonable or illogical (695). I agree that Donne (or at least the speaker) recognizes that he should not advance any argument against God, but I disagree that the protests are well-founded or even true. Rather the point of the climax is that any argument against God is specious (that is, false) precisely because it subjects God to an objective standard of rationality which he must obey, a subjection which denies God his omnipotence and therefore his claim to be God. Even when one formulates the third protest of the octave as essentially asking the question "Why should not a loving god save everyone?" this does not mean that, as Alan Sinfield thinks, "there is no good answer, and Donne does not pretend otherwise" in his outcry to God. ${ }^{12}$ On the contrary, the speaker's outcry to God acknowledges that the argument has already been answered by Paul and shown to be invalid in its suppression of the fact that justice, as well as mercy, is a fundamental attribute of God and also brings him glory. Moreover, as Strier notes, the speaker mistakenly treats intent or reason "as if it were a mere natural property, like a physical characteristic over which the agent has no control," and thinks that it "has no internal relation to the concept of sin" (382). But, again, this does not mean that the argument (according to Strier) is "transparently sophistical" or "obviously fallacious" (382). Apart from the fact that the readings of Stachniewski and Sinfield show an inability to observe what is supposedly perspicuous, the first eight lines of the poem invite us to accept its complaints, since the objec- 
tions the speaker makes are grounded partly in truth: animals are in fact not damned, but we are; God is in fact merciful yet threatens man. That is to say, the argument is initially persuasive because the speaker has a prima facie reason for complaining; and it is only when the speaker chastises himself that he recognizes that it is specious.

It should be noted, in passing, that the strategy I have been documenting is not unlike the one that Donne uses in some of his devotional works. A case in point is the twenty-second expostulation of his Devotions upon Emergent Occasions, in which Donne observes that "Any thing serves, to occasion sin, at home, in my bosome, or abroad, in my Marke, and aime; that which I am, and that which I am not, that which I would be, proves coales, and embers, and fuell, and bellowes to sin." 13 Yet the fact that sin is occasioned by all circumstances, whether they are external or internal, prompts him to question God:

... and does thou put me, $\mathrm{O}$ my God, to discharge my selfe, of my selfe, before I can be well? When thou bidst me to put off the old Man, doest thou meane, not onely my old habits of actuall sin, but the oldest of all, originall sinne? When thou biddest me purge out the leven, does thou mean, not only the sowreness of mine owne ill contracted customes, but the innate tincture of sin, imprinted by Nature? How shall I doe that which thou requirest, and not falsifie that which thou has said, that sin is gone over all? (119)

Together and individually, each of these questions brings into focus a demand that seems impossible to fulfill: to rid oneself not only of actual sin but of original sin, "the innate tincture of sin" that is both the cause of all "old habits" (as we are told a few lines earlier) and everywhere present within the self. But if sin is not localized but all-pervasive - if it is, as God allegedly says, "gone over all"- - then such an action would be necessarily incomplete without the wholesale destruction of the self ("does thou put me, O my God, to discharge my self, of my selfe"). In short, to obey the command "put off the old Man" (short of self-destruction) is also to contradict or disprove ("falsifie") another part of God's word, an (almost blasphemous) conclusion that Donne withdraws from in the next line: "But, O my God, I presse thee not, with thine owne text, without thine owne comment" (119).

After the author corrects himself of his previous expostulations, he proceeds to reconcile the two aspects of God's word that initially seemed contradictory to him:

I know that in the state of my body, which is more discernible, than that of my soule, thou dost effigiate my Soule to me. And though no Anatomist can say... here lay the coale, the fuell, the occasion of all bodily diseases, but yet a man may have such knowledge of his owne constitution, and bodily inclination to diseases, as that he may prevent his 
danger in a great part: so though we cannot assigne the place of originall sinne, nor the Nature of it, so exactly as of actuall, or by any diligence devest it, yet having washed it in the water of thy Baptisme, wee have not onely so cleansed it... but so weakned it, that howsoever it may retaine the former nature, it doth not retaine the former force. (119)

The reconciliation forms the foundation for the concluding prayer, in which Donne affirms the graciousness of God and repents of his importunities: "O our good, but fearefull God: Thou pardonest no sinne so, as that that sinner can sinne no more; thou makest no man so acceptable, as that thou makest him impeccable... yet were it an irregular anticipation, and an insolent presumption, to thinke that thy present mercie extended to all my future sinnes, or that there were no embers, no coales of future sinnes left in mee. Temper therefore thy mercie so to my soule" (120). This pattern of expostulation and correction-one that is encouraged by the ostensible structure of the meditation itself-occurs repeatedly throughout the Devotions; and it is a pattern that typically results in a rehearsal of Scripture in its proper theological context and so leads to a correct knowledge of God. ${ }^{14}$

It is this kind of knowledge, which the speaker momentarily fails to remember before it is brought back into consciousness (the poem does not say which agent, if any, brought this about), that makes him realize that he has denied God in his protests and sinned against him. Consequently, he weeps in repentance:

... Oh! of thine onely worthy blood, And my teares, make a heavenly Lethean flood, And drowne in it my sinnes blacke memorie. That thou remember them, some claime as debt, I thinke it mercy, if thou wilt forget. (10-14)

Paradoxically, the speaker's remembrance of the true nature of God compels him to ask for the forgetfulness of his own: he asks that the "blacke memorie" of his sins be drowned in a "heavenly Lethean flood" composed of blood and tears. Here the phrase "heavenly Lethean flood" refers not only to the river in Hades that contains the waters of forgetfulness but to the (heavenly) flood that destroyed the corrupt earth and its wicked inhabitants in the time of Noah. In other words, the speaker feels that the extent of his sins is so great ("blacke") that he must enlist both heavenly and diabolical powers, past and present, to erase them. And the speaker feels such guilt because he now realizes that he had falsely assumed that it is easy for God to have mercy ("mercie being easie ... / To God), whereas in reality mercy is not easy for the God whose precious blood was shed for it ("thine onely worthy blood"). When the speaker no longer presumes on God's mercy, so does the reader: 
that is, the reader is compelled to repent and seek forgiveness as the speaker asks God to forget, to include himself in the house of Israel to which God says, "I will be merciful to their unrighteousness, and their sins and their iniquities will I remember no more."15

In making this point, it is worth noting that the speaker is not asking, as Strier thinks, that he be forgotten, since it is unlikely that the "them" in "thou remember them" refers to persons but to "sinnes," and therefore to maintain the parallel structure in the final couplet the object of "thou wilt forget" should be "them" rather than "me."16 To be sure, the pronoun "them" is ambiguous - it could refer to the "sinnes" in "my sinnes blacke memory" or to "some" in "some claime as debt"; and if the referent is the latter it "curiously praises," Michael C. Schoenfeldt tells us, "as an act of divine mercy what George Herbert, in the conclusion of 'Affliction (I),' depicts as the ultimate psychological terror: being forgotten by God." 17 It is this possibility that makes Strier claim that the "sense of sin and the fear of God in this poem are so profound that being forgotten replaces being forgiven as the alternative to damnation," and therefore Donne departs from a Calvinist understanding of justification and shows himself to be idiosyncratic in his belief (383-84). Such a claim, however, neglects the other referent of "them" (i.e., "sinnes") and the possibility that "some" could simply refer to some people other than the speaker, an interpretation that makes sense of the immediate context and is able to maintain the poem's integrity, both thematically and structurally. As Susan Linville accurately explains, what is being asked to be erased "is not only the speaker's memory of his sins ... but God's memory of them as well. In fact, the speaker's forgetting, we can infer, is dependent upon God's prior act of mercy in the forgiveness and forgetting of these sins." 18 In other words, the speaker can forget his sins only when God has forgotten them, a forgiveness that presupposes that God remember them first. Thus, the speaker is asking in the sestet that his "sinnes blacke memory" be drowned and forgotten (they are the same action), and such a request is not idiosyncratic to Donne, but aligned with an understanding of mercy found in Scripture.

This, of course, should not be surprising when we consider that the strategy that Donne uses in the whole sonnet - the strategy of entertaining a set of rationalizations before chastising the one who entertained them-is the same as the one used by Paul in his epistle to the Romans. It is a strategy that not only imitates the movement and rhetorical strategy of the ninth chapter in that epistle but brings to mind (in the speaker and the reader) its content, which shows, at the point of chastisement, that the argument the speaker advances is in fact specious. ${ }^{19}$ It is a specious argument because it does not take into account the nature of God and his counterintuitive ways; it fails to 
register that God in his righteousness can exercise mercy or wrath on whomever he pleases, and that either choice can result in his glory; and it presumes that humans are in a position to judge the way in which God acts. Indeed, the argument the speaker presents is a demonstration of his sinfulness, and his call to God to forget his sins is also a call to God to forget the argument of the first eight lines. But if the speaker wants to forget the argument of the octet, why then does Donne write those first six lines? Why record an argument that has already been repented of? These questions only present a problem if one assumes that the speaker is in fact Donne and that the Holy Sonnets thus give insight into his spiritual autobiography and correspond to his personal beliefs and struggles with God (a view that has more or less been articulated by such critics as K. W. Grandsen, Helen Gardner, R. C. Bald, A. J. Smith, Helen S. Thomas, John Carey, George A. E. Parfitt, John Stachniewski, and Richard Strier). ${ }^{20}$ Within this view, however, it makes no sense for Donne to record the same transgressions that he wants to forget; indeed, the writing of the poem compels its own erasure. But the problem disappears when the poem is understood not simply as a personal record of Donne's belief but rather as a public model for religious devotion, that is, as a poem formed after a pattern or pedagogy found in Scripture with the purpose of reforming its unreformed readers. ${ }^{21}$ This is not to say that Donne's religious beliefs and convictions do not inform the sonnet (they certainly do); it is just to say that they do not directly correspond to every utterance in the poem, since those beliefs and convictions are expressed (variously) through a persona, a speaker who in his alliance with the speech-in-character of the teacher and the imaginary person found in Romans is used to shape the moral characters of all who listen. ${ }^{22}$ The reason, then, that Donne records the argument of the sonnet is to bring his unrepentant readers to repentance. But in order to remember that you are in need of mercy you need to remember that you are still sinful; and that is accomplished not by repeatedly being told that you are sinful but by demonstrating that sinfulness as you identify with the speaker's complaints. And that sinfulness is what we finally must never forget (at least not for more than a moment); for if we do, we might perversely think that we do not deserve to be damned.

\section{Princeton University}

Notes

I would like to thank William Walker and Gregory Kneidel for their comments and suggestions on earlier versions of this article. 
1. John Stachniewski, "John Donne: The Despair of the Holy Sonnets," English Literary History 48 (1982), p. 694. Subsequent page references are cited in parentheses in the text.

2. Barbara Lewalski, Protestant Poetics and the Seventeenth-Century Religious Lyric (Princeton: Princeton University Press, 1979), p. 269.

3. Richard Strier, “John Donne Awry and Squint: The 'Holy Sonnets,' 1608-1610,” Modern Philology 86 (1989), p. 382. Subsequent page references are cited in parentheses in the text.

4. Romans 9:3. References to the Bible are taken from the Authorised Version (1611). Spelling has not been modernized.

5. James Tully, An Approach to Political Philosophy: Locke in Contexts (Cambridge: Cambridge University Press, 1993), p. 293.

6. J. B. Schneewind, The Invention of Autonomy: A History of Modern Moral Philosophy (Cambridge: Cambridge University Press, 1998), p. 8.

7. Martin Luther: Selections From His Writings, ed. John Dillenberger (New York: Anchor Books, 1961), p. 195. Subsequent page references are cited in parentheses in the text.

8. Stanley K. Stowers, A Rereading of Romans: Justice, Jews, and Gentiles (New Haven: Yale University Press, 1994), p. 20. Subsequent page references are cited in parentheses in the text.

9. 11. 1-4. I am using Helen Gardner's edition of the Holy Sonnets, in John Donne: The Divine Poems, 2nd edn. (1952; Oxford: Oxford University Press, 1978). Subsequent references to the lines of this poem are cited in parentheses in the text.

10. Of course, some commentators have observed that this line in the poem alludes to Romans 9:20, but observing that Donne echoes these words of scripture is about as far as they go. See, for example, Lewalski, p. 269. My essay, in contrast, shows not only that this line alludes to the verse in Romans, but that the whole poem adopts the rhetorical strategy of the first 24 verses of Romans 9.

11. P. M. Oliver, Donne's Religious Writing: A Discourse of Feigned Devotion (London and New York: Longman, 1997), p. 124.

12. Alan Sinfield, Faultines: Cultural Materialism and the Politics of Dissident Reading (Oxford: Clarendon Press, 1992), p. 161.

13. John Donne, Devotions Upon Emergent Occasions, ed. Anthony Raspa (Oxford: Oxford University Press, 1987), p. 119. Subsequent page references are cited in parentheses in the text.

14. Other meditations of the Devotions in which this rhetorical strategy is evident include 6, 17, and 21. Expostulatio is also discussed by Donne in a sermon preached in 1620 at Lincoln's Inn. Drawing on the Old Testament examples of Abraham, Jacob, Moses, David, and Amos, Donne asserts that "God admits, even expostulation, from his servants; almost rebukes and chidings from his servants." The charges that each of these characters make against God - even to the extent that perjury is imputed to God himself - are nevertheless grounded, Donne argues, upon the foundation that "It is impossible, that the Iudge of all the earth should not do right." See The Sermons of John Donne, ed. Geroge R. Potter and Evelyn M. Simpson, 10 vols. (Berkeley and Los Angeles: University of California Press, 1957), vol. 3, pp. 145-46. 
15. Hebrews 8:12. Here the author of Hebrews is quoting the prophet Jeremiah who predicted a new covenant in which God would be reconciled to his people (see Jeremiah $31: 31-34)$.

16. Strier claims, on the contrary, that "Line 13 is about persons, not sins" (p. 384).

17. Michael C. Schoenfeldt, "The Poetry of Supplication: Toward a Cultural Poetics of the Religious Lyric," New Perspectives on the Seventeenth-Century English Religious Lyric, ed. John R. Roberts (Columbia and London: University of Missouri Press, 1994), p. 82.

18. Susan Linville, "Donne's Holy Sonnets IX," The Explicator 36:4 (1978), p. 21. For a different view of the final couplet, an interpretation in which the referent of "them" is understood as something other than sins, see Stanley Archer, "Donne's Holy Sonnets IX," The Explicator 30:1 (1971), item 4.

19. I should note that Milton also follows Donne here in some of his sonnets. See in particular "Sonnet VII: How Soon Hath Time," in which the speaker chastises himself by shutting down in the sestet his earlier anxiety that he has nothing to show for his work-"no bud or blossom show'th" - by his “three and twentieth year!" See John Milton: Complete Poems and Major Prose, ed. Merritt Y. Hughes (1957; Indianapolis: Hackett, 2003), 11. 1, 4.

20. See K. W. Grandsen, John Donne (London: Longmans, 1954), pp. 127-38; R. C. Bald, John Donne: A Life, ed. Wesley Milgate (New York and Oxford: Oxford University Press, 1970), pp. 233-36; A. J. Smith, "The Poetry of John Donne," English Poetry and Prose: 1540-1674, ed. Christopher Ricks (London: Barrie \& Jenkins, 1970), pp. 16163; Helen S. Thomas, "The Concept of the Persona in John Donne's Religious Poetry," Southern Quarterly 14 (1976), pp. 183-89; John Carey, John Donne: Life, Mind and Art (New York: Oxford University Press, 1981), pp. 48, 57-58; George A. E. Parfitt, English Poetry of the Seventeenth Century (London and New York: Longman, 1985), pp. 42-43; and the articles cited in this essay by Stachniewski and Strier.

21. Jeffrey Johnson notes that while the Holy Sonnets have been often discussed as "prayerful utterances, only a few have explored the rhetorical implications of this connection." He finds that the "orthodoxy" of the "prayerful struggle" in Donne's religious poetry, which aims "to procure assurance of salvation," both "echoes the language of the Psalms" and also "suggests a public dimension for these poems as devotional models." My intention in this essay has been to explore the rhetorical implications of Donne's prayerful utterances, although the connection between them and scripture is slightly different since, I argue, Donne draws on Pauline rhetoric in Romans (rather than the language of the Psalms) in the sonnet I discuss. (This is not to say that Donne is not drawing on the Psalms at all, only that the parallel with Romans is the primary one.) Nonetheless, the echoes of the language of that epistle and the imitation of its rhetorical strategy suggest a "public dimension" for the poem, a dimension that Johnson claims for all of Donne's religious poetry. See Johnson's The Theology of John Donne (Cambridge: D. S. Brewer, 1999), p. 48.

22. Here I am in agreement with Gary Stringer, who, in his reply to Helen S. Thomas (note 20, above), believes that "Donne orchestrated the material [of the twelve Holy Sonnets of 1609] to a didactic end." As a result, "we will be required to discern a persona whose identity has been especially created for the occasion and whose fortunes are exhibited through the twelve episodes of a carefully structured sequence." See Gary Stringer, “Donne's Religious Personae: A Response," Southern Quarterly 14 (1976), p. 192. 